\title{
Madames e mademoiselles nas revistas curitibanas do início do século XX
}

\author{
Madames and mademoiselles in illustrated magazines of Curitiba city in \\ early twentieth century
}

Rosane Kaminski ${ }^{1}$

\begin{abstract}
RESUMO
Este artigo discute o lugar da mulher nas revistas ilustradas em Curitiba no início do século XX. Observa as principais formas pelas quais a mulher foi representada nas revistas, e pondera sobre os limites da atuação da mulher como produtora de textos e imagens para esses periódicos.
\end{abstract}

PALAVRAS-CHAVE: Revistas ilustradas. Curitiba. Mulher.

\section{ABSTRACT}

This paper examines the role of women in illustrated magazines of Curitiba city in early twentieth century. In this way, it analyses the main ways of women's depiction in the magazines, and discusses the boundaries of women's activities as magazine writers and illustrators.

KEYWORDS: Illustrated magazines. Curitiba. Woman

$$
* * *
$$

\section{Revistas e mulheres na Curitiba do início do século XX}

Apesar de ser pouco populosa e ter um modesto público de leitores nas décadas iniciais do século XX, Curitiba experimentava, a seu modo, a expansão dos periódicos impressos e a diversificação crescente de suas funções sociais. Revistas literárias, humorísticas, institucionais e de variedades apareciam nas bancas de forma tão rápida quanto eram extintas ${ }^{2}$.

\footnotetext{
1 Rosane Kaminski. Programa de Pós-graduação em História da UFPR, Brasil. E-mail: rosanekaminski@ufpr.br

2 Numa pesquisa realizada entre 2008 e 2010, com auxílio do Edital Universal do CNPq, foram levantados cerca de sessenta títulos de revistas publicadas em Curitiba entre 1900-1920, quase todas de existência efêmera. Ver: KAMINSKI, 2012. Para maiores detalhes, consultar o material sistematizado no site: http://www.revistascuritibanas.ufpr.br
} 
A presença das mulheres nessas revistas se fez ver de maneiras variadas. As mais comuns eram a publicação de fotografias das mademoiselles da sociedade paranaense, as charges que ironizavam o comportamento da mulher, a moda inspirada em Paris, os trejeitos e os novos espaços de socialização urbana, como também a publicidade direcionada ao consumo feminino e o uso da imagem da mulher para vender produtos diversos.

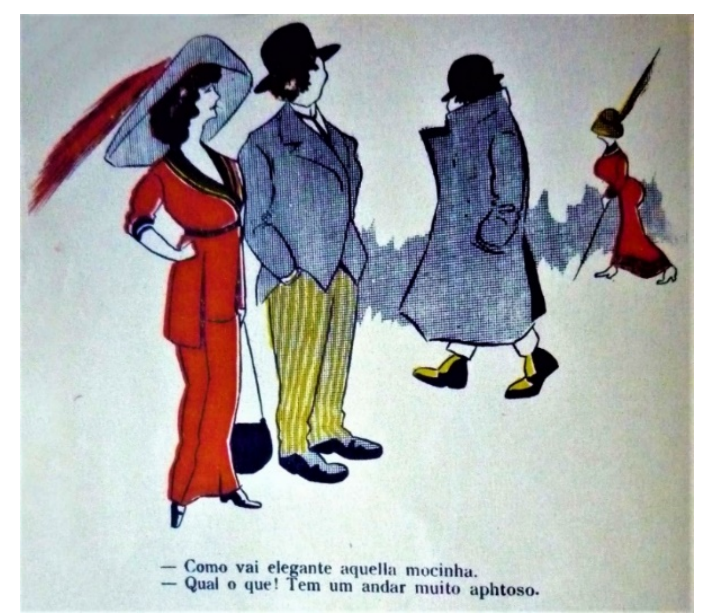

FIGURA 1: Charge publicada na Revista $A$ Bomba n ${ }^{\circ}$ 3, Curitiba, 1913, p.32.

- Como vai elegante aquella mocinha.

- Qual o que! Tem um andar muito aftoso.

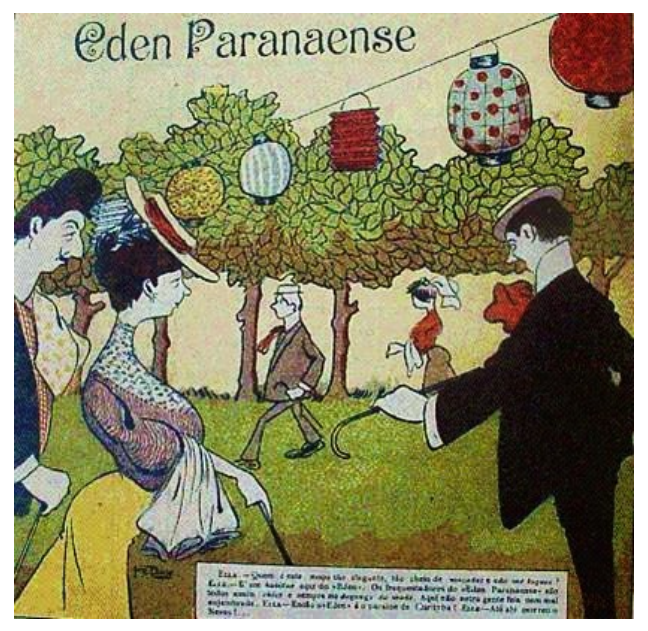

FIGURA 2: Publicidade do parque de diversões Eden Paranaense. Revista A Carga no 7 . Curitiba, 1907, s/p.

Há alguns estudos já publicados que debatem os usos publicitários e a representação humorística da mulher em revistas ilustradas, apontando para uma ambiguidade dessas produções. Por um lado, as charges ridicularizavam as conquistas femininas, reforçando o ideal masculino de dominação e exclusão da mulher, mas, por outro lado, revelavam "mudanças nos padrões de comportamento e de sentimentos frente às novas experiências urbanas" (QUELUZ, 2006, p. 21) ${ }^{3}$. Outra forma de figuração feminina estudada por Marilda Queluz (1996, p.75-84) são os usos metafóricos da mulher para representar a Imprensa, a República, a Instrução, a Política a Música e a Poesia. No caso regional de disputa pela demarcação de territórios estaduais, observa-se a Província de Santa Catarina, seja como uma "senhora perspicaz"

\footnotetext{
3 Além desse e outros artigos de Marilda Queluz sobre as charges que ironizam o comportamento da mulher, vale mencionar também os estudos de TEIXEIRA (2014).
} 
(Figura 3) ou como uma "santa embusteira" (Figura 4), em contraposição à figura masculina do Paraná ou do "Zé Paranaense" que reage às artimanhas da santa / mulher ${ }^{4}$.

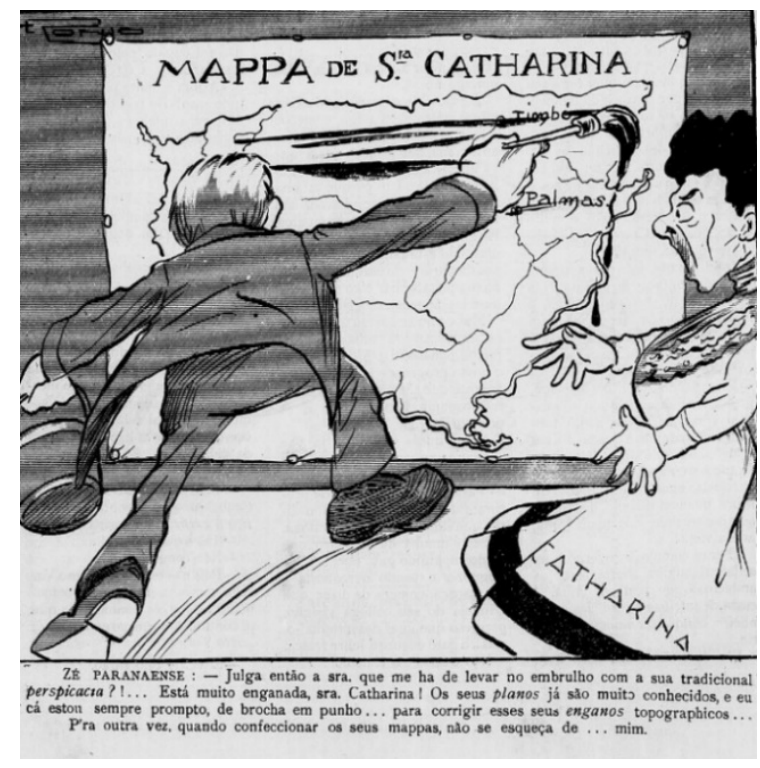

FIGURA 3: Segunda capa de $O$ Olho da Rua, $\mathrm{n}^{\circ} 38$, outubro de 1908. [detalhe] Charge elaborada por Herônio (Mário de Barros).

Zé Paranaense: - Julga então a sra. que me há de levar no embrulho com a sua tradicional perspicácia?!... Está muito enganada, Sra. Catharina! Os seus planos já são muito conhecidos, e eu cá estou sempre prompto, de brocha em punho...para corrigir os seus enganos topoghaphicos... P'ra outra vez, quando confeccionar os seus mapas, não se esqueça de... mim.

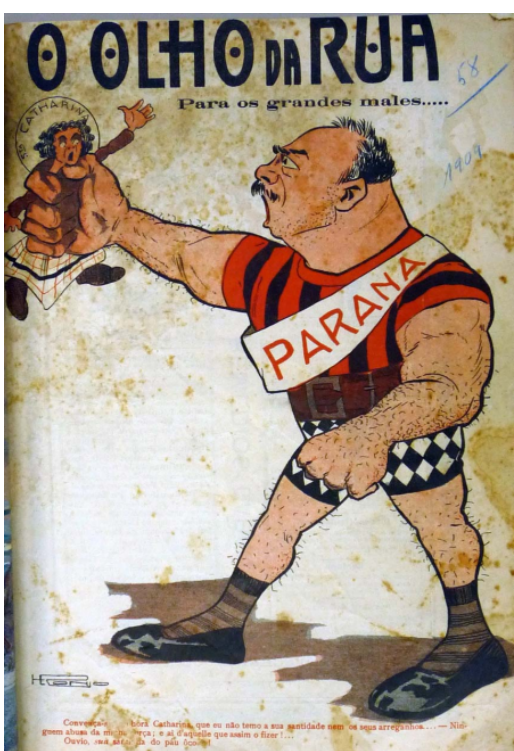

FIGURA 4: Capa de O Olho da Rua, $\mathrm{n}^{\circ}$ 58, setembro de 1909. Charge elaborada por Herônio (Mário de Barros).

\section{PARA OS GRANDES MALES...}

Paraná: - Convença-se, senhora Catharina, que eu não temo a sua santidade nem os seus arreganhos... ninguém abusa de minha força; e ai d'aquelle que assim o fizer!... Ouvio, sua santinha do páu ôco?

Outro ponto que merece destaque, quanto aos usos da imagem feminina, é que o processo de modernização de Curitiba ao longo da Primeira República foi permeado pelo ideal de civilização, que articulava o refinamento de hábitos e a docilização dos costumes aos ideais de ordem e progresso.

Havia, naquele processo, uma estreita relação entre "civilizar" e "docilizar", indicando que a cidade ideal é feminina (CUNHA, 2001, p.42). A imagem de Curitiba alegorizada em mulher jovem e atraente foi, inclusive, tema de algumas charges que circularam por ocasião da visita do Presidente

\footnotetext{
${ }^{4}$ Desde 1853, ano da emancipação da Província do Paraná, a disputa territorial com Santa Catarina vinha se arrastando. Em 1901, Santa Catarina reivindicou a posse de todo o território contestado. "A decisão do Supremo Tribunal Federal ocorreu em 1904 e os embargos apostos pelo Estado do Paraná foram julgados em 1909 e 1910, todos dando ganho de causa ao Estado de Santa Catarina". (WACHOWICZ, 2010, p.233). A publicação dessas charges ocorreu no auge dessas disputas.
} 
eleito Afonso Pena à capital do Paraná (Figura 5). Como era usual na forma de encarar a mulher, nessa cena ela se veste ao gosto da moda da época, apresentando-se como "desejável” perante o olhar masculino do Presidente, do chargista e do público potencial da charge.

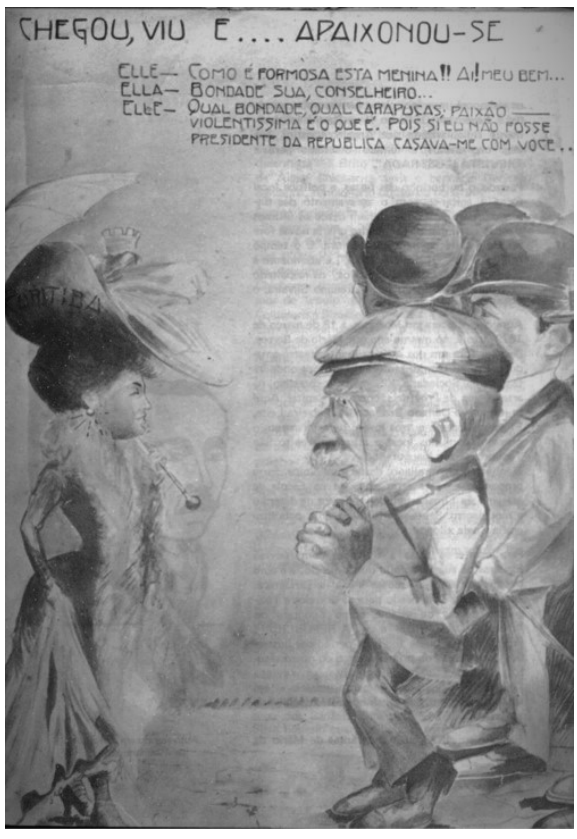

FIGURA 5: Charge elaborada por Herônio (Mário de Barros) em 1905, representando um diálogo entre Afonso Pena e Curitiba. (CARNEIRO, 1975, p.44-45).

CHEGOU, VIU E...APAIXONOU-SE

ELLE - Como é formosa esta menina! Ai! Meu bem!

ELLA - Bondade sua, Conselheiro...

ELLE - Qual bondade, qual carapuças; paixão violentíssima é o que é. Pois si eu não fosse Presidente da República casava-me com você...
No entanto, para além das representações visuais do feminino, são esparsos os estudos sobre as outras formas da presença da mulher nesse universo midiático. Por exemplo, sobre a mulher enquanto público alvo, no caso das colunas (escritas por homens) dedicadas às mulheres e da publicação de revistas específicas ao público feminino, ou, ainda sobre a mulher produtora de conteúdo.

Era usual a colaboração de mulheres na publicação de contos, poemas ou comentários sobre a moda nas revistas curitibanas de então, inclusive em colunas regulares, como aquela assinada por Marianna Coelho no jornal Diário da Tarde, a partir de 1901, ou a assinada por Madame Charlotte na

revista Paraná Moderno, em 19115. Havia, também, esporádicas publicações de textos sobre a emancipação da mulher, lembrando que o movimento feminista aportava em Curitiba na virada do século, fomentando polêmicas (TRINDADE, 1992, p. 113). O mais raro, quase ausente, foi a presença da mulher como produtora de imagens, sejam elas charges, ilustrações ou

\footnotetext{
${ }^{5}$ Não é possível ter certeza sobre a identidade de Madame Charlote, talvez seja um pseudônimo, assim como o caso da M.me Quelque Chose (Directeure de la revue feminine L'Esculhambation), que ironiza a presença feminina na mídia impressa, na Revista $A B_{0 m b a}{ }^{\circ}$ 5, Curitiba, 1913, p.18.
} 
fotografias, fato também observado em outros centros latino-americanos (FAKIN, 2019, p.20).

Considerando a presença da mulher como elemento passivo (assunto) ou como elemento ativo (autora de letras e imagens), pretende-se discutir, neste texto, algumas de suas presenças no rico contexto gráfico observável na Curitiba do início do século XX, e problematizar o lugar da mulher no âmbito da produção visual, destinada majoritariamente aos homens. Naquele período, revistas como O Olho da Rua (1907-1911), Paraná Moderno (1911), A Bomba (1913), Revista do Povo (1916-1920), Sulina (1919) e Senhorita (1920) destacaram-se pela abundância de imagens sobre a mulher e pelas seções e textos assinados por mulheres ou, no caso da última, por se destinar exclusivamente ao público feminino.

Com o intuito de melhor compreender as raras aparições de imagens cujas autoras são mulheres, o percurso narrativo deste texto inclui observações sobre o contexto cultural de Curitiba, as formas de visibilidade difundidas na época, e também sobre a presença de ideias feministas. Em seguida serão ponderados os limites para a atuação da mulher no âmbito da criação visual. A observação de algumas imagens e textos feitos por mulheres ou referentes à mulher permitirão interpretar e problematizar o seu lugar nos debates culturais e comportamentais do período.

\section{A misteriosa Mademoiselle Chy, as artes visuais e algumas pitadas de feminismo em Curitiba}

Em dezembro de 1913, numa notinha de pé de página da revista $A$ Bomba, saiu a seguinte informação:

Entrou para o corpo de collaboração d' 'A Bomba' a espirituosa senhorita que se occulta sob o pseudonymo de Mlle. Chy. Possuidora de um lapis firme, caprichoso e rico de verve. Mlle. Chy d'ora avante deliciará as pessoas que nos 
lêem com os seus interessantes trabalhos caricaturaes. (A BOMBA n.20-21, $1913, \mathrm{p} .13)^{6}$

Alguns meses antes, na primeira edição da revista, ocorrida em junho de 1913, o editorial avisava que "o corpo de colaboração da Bomba acha-se representado no que há de mais notável em nosso meio artístico e literário" (A BOMBA n.1, 1913, p. 28). Até então, todas as imagens publicadas nessa revista humorística haviam sido assinadas por homens, seja por meio de pseudônimos, no caso das charges, ou pela indicação da autoria das reportagens fotográficas, atribuídas ao Estúdio de Fotografia Volk e a Arthur Wischral7.

A informação, portanto, trazia uma novidade inusitada: uma mulher fazendo charges! Algo inédito naquele contexto em que a produção de imagens era reservada quase que exclusivamente aos homens ${ }^{8}$. A própria charge publicada pela misteriosa Mademoiselle Chy refere-se a esse espaço profissional masculino, mostrando um pintor comercializando seus quadros, num precário meio artístico (Figura 6).

\footnotetext{
${ }^{6}$ Saiu na mesma página um texto de Rodrigo Junior (o mesmo poeta seria responsável pela publicação da revista $A$ Senhorita, em 1920, dedicada ao público feminino). A nota foi provavelmente escrita por ele, um dos redatores literários da revista $A$ Bomba.

7 Essa informação saía no editorial da revista a cada edição de $A$ Bomba, que também apontava os nomes de Marcello Bittencourt como proprietário da revista, dos poetas Rodrigo Junior e Clemente Ritz como redatores literários e de "Felix" como redator artístico. A Bomba saía nos dias 10, 20 e 30 de cada mês, e cada exemplar era vendido por 400 réis.

8 Sobre o perfil dos criadores de imagens e textos para as revistas curitibanas, ver: KAMINSKI, 2017.
} 


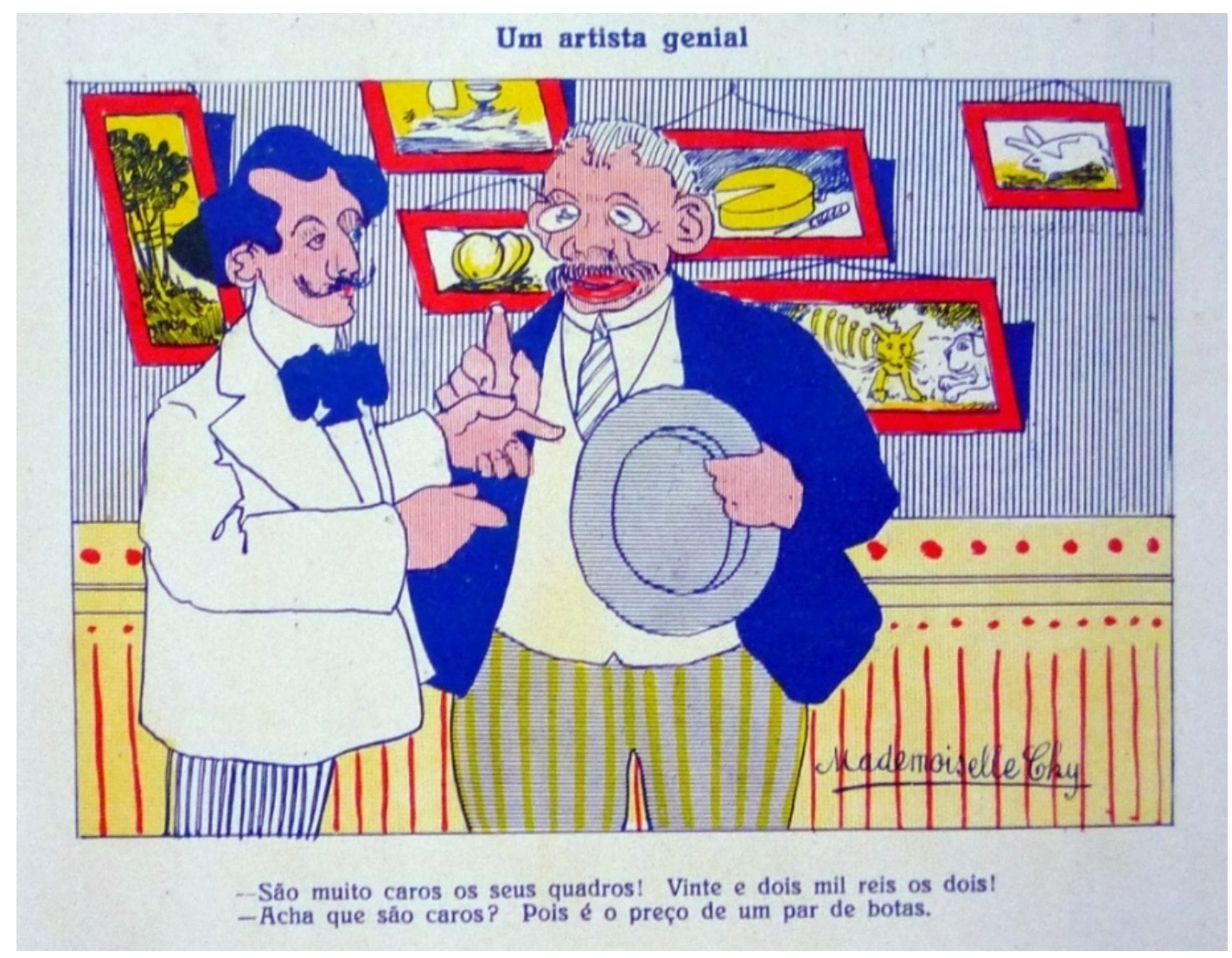

FIGURA 6: Charge assinada por Mademoiselle Chy. A Bomba, 31 dez. 1913 n20-21, p.30.

- São muito caros os seus quadros! Vinte e dois mil reis os dois!

- Acha que são caros? Pois é o preço de um par de botas.

A charge evoca o tema do mercado da arte em tom satírico. A imagem do pintor com o terno branco, colarinho alto, gravata borboleta e os bigodes à la Salvador Dali, estiliza o afrancesamento da cultura local, ou do gosto francês tomado como "melhor" e mais refinado do que os hábitos rudes dos imigrantes europeus que trabalhavam na agricultura e no comércio curitibano ${ }^{9}$.

Aliás, é esse o tema da charge: apesar de bem vestido, o comprador é um homem pouco refinado no trato com a arte. A imagem não evoca um "imigrante europeu”, pois seus traços representam um homem negro, etnia estilizada nos lábios grossos e vermelhos. De qualquer modo, ele se distingue do artista por ser mais velho, mais gordo, e vestir-se com estilo mais conservador. Um homem de classe média curitibana, que não valoriza

\footnotetext{
${ }^{9}$ Em outros textos, já tratei da importância que era dada aos modelos comportamentais franceses na Curitiba do início do século XX, em detrimento do modelo alemão e de outras nacionalidades comuns aos imigrantes que viviam na cidade e seus arredores. Ver: KAMINSKI, 2010, p.4-8 e KAMINSKI, 2012, p. 248-255.
} 
devidamente o trabalho do artista, uma vez que reclama do preço elevado de um "par de obras". Provavelmente um "par" que ele estaria negociando, mas queria pechinchar, como nas práticas comuns diárias. A abordagem frente ao objeto artístico é similar ao comércio de qualquer outro objeto. A resposta irônica do pintor o situa como leigo, ao adotar a linguagem que o comprador entende, comparando o preço das duas obras de arte ao preço de um par de calçados. Se fôssemos tentar entender o gosto de um suposto público consumidor de arte naqueles anos através das representações de quadros que existem na charge, teríamos poucos subsídios para realizar esta análise, pois todas as "telas" estão estilizadas em traços rápidos e caricaturais. Entretanto, pelas suas próprias características visuais, a charge informa sobre o gosto difundido entre o público consumidor das revistas - o mesmo público que frequentava as sessões de cinematógrafo, os parques e os cafés.

$\mathrm{O}$ estilo da imagem (a charge), ainda que com traços ingênuos, é claramente referenciado nas artes gráficas do art nouveau europeu, com as figuras delineadas por contornos delicados e por massas planas de cor, eliminando degradês ou simulação de volume nas roupas e pele dos personagens. Os espaços da imagem são preenchidos ora por cores puras, ora por texturas lineares, valorizando a bidimensionalidade do papel. A limitação da impressão às três cores primárias intensifica o aspecto de estilização.

A adesão do gosto dos consumidores curitibanos à visualidade do art nouveau, sobretudo o francês, foi construída gradualmente. As revistas de humor ajudaram a difundi-lo, já que eram fartamente ilustradas e versavam sobre assuntos do cotidiano na cidade, atuando como "vitrinas" do comportamento do homem urbano.

Esses dados são significativos frente ao contexto de produção e circulação dessa charge, em 1913, num momento em que Curitiba mal esboçava a existência de um meio artístico. Afora a produção de materiais gráficos e fotográficos que se processavam na cidade há menos de três décadas, havia na cidade uma Escola de Belas Artes e Indústrias do Paraná, originalmente criada pelo português Mariano de Lima em 1886 como Aula de Desenho e Pintura, e um atelier de desenho e pintura, de propriedade do 
pintor norueguês Alfredo Andersen, que se estabeleceu em Curitiba a partir de $1902^{10}$. Também era desde 1902 que a escola criada por Mariano de Lima vinha sendo dirigida por uma mulher, D. Maria da Conceição Aguiar Lima ${ }^{11}$. Ainda assim, o meio artístico era pouco profissionalizado, com escasso apoio das classes dirigentes. Não havia recursos materiais, eram precárias as instâncias de exibição e de formação de um público apreciador de arte. Os artistas tinham dificuldades para se manter e a crítica apontava para uma "mediocridade" na produção e consumo de arte ${ }^{12}$. Num balanço publicado em 1922 sobre as artes no Paraná, Laertes Munhoz discorreu sobre as dificuldades de obtenção de reconhecimento público por parte dos artistas, bem como as divergências de opiniões em relação ao lugar conquistado por Alfredo Andersen, único artista com formação acadêmica residente na cidade, no cenário da pintura curitibana ao longo daquelas duas décadas.

Ou seja, enquanto as ilustrações das revistas chegavam ao público pela via do humor e da publicidade, fazendo assentar um gosto visual a partir de suas diagramações, ornamentos e estilizações, um dos problemas enfrentados pela pintura seria justamente o despreparo do público para lidar com os

\footnotetext{
10 Somente a partir da década de 1880 começou a se formar, em Curitiba, um espaço para produção visual, por meio da chegada de alguns europeus que atuavam na área: o fotógrafo H.A. Volk que montou um estúdio à rua do Imperador, ao lado de sua esposa Fanny Paul Volk; o litógrafo catalão Narciso Figueras que passou a ensinar a técnica da litografia para alguns aprendizes em sua oficina gráfica; e o português Mariano de Lima - que veio a Curitiba em 1884 para fazer a cenografia do Teatro São Teodoro e acabou se instalando na cidade. Em 1886 conseguiu apoio do governo estadual e fundou uma escola de ensino de artes, A Aula de Desenho e Pintura, abrindo uma senda para a formação de um interesse pela arte e suas funções sociais. As aulas de Mariano de Lima funcionaram nas instalações do Instituto Paranaense, inicialmente sem mobiliário e sem modelos por falta de verba. Anos mais tarde, em 1902, a chegada do norueguês Alfredo Andersen, detentor de uma fina erudição pictórica construída durante os anos em que frequentou a Academia Real de Belas Artes de Copenhague, veio trazer algum vigor à produção visual na cidade. Foi ele o primeiro artista a expor individualmente em Curitiba, no ano de 1902, quando também passou a ministrar aulas de desenho e pintura em ateliê próprio. Nesse mesmo ano, Mariano de Lima partiu para a região norte, deixando sua escola aos cuidados da ex-aluna e esposa, Maria da Conceição Aguiar Lima. Para maiores detalhes sobre esses assuntos, ver: KAMINSKI, 2012; SANTANA, 2004; SIMÃO, 2010; BUSNARDO, 2018.

11 "Com a saída de Mariano de Lima em 1902, sua esposa, Maria da Conceição Aguiar Lima, assumiu a direção da escola, que então teve sua orientação alterada para dar maior ênfase à educação de artes e ofícios para mulheres - tanto que, a partir de 1917, ganhou a denominação de "Escola Profissional Feminina". SANTANA, 2004, p.9.

12 "Medíocre" foi um termo usado por Laertez Munhoz para se referir ao meio artístico curitibano num longo artigo publicado no jornal Gazeta do Povo em 1922. Ele diz: "Curityba pode ser um meio artístico mediocre. O que se lhe não nega, é uma grande superioridade sobre outras capitaes do sul. Florianópolis e Porto Alegre não tem a cultura da capital paranaense.[...] Em compensação, confrontando-se Curityba com São Paulo e Rio de Janeiro, experimenta-se umas espécie de desânimo, porque esses dois centros que são verdadeiramente cultos, estão muitas e muitas vezes acima”. (MUNHOZ, 1922, p.62).
} 
rituais sociais de produção, exibição e consagração de obras de arte. A descrição de Munhoz é elucidativa da situação:

O pintor expõe. Consegue uma ligeira crítica sobre os seus quadros, com alguns amigos que trabalham no jornal. Um ou outro visitante apparece no salon. Vê os quadros, corre os olhos no catálogo, passeia a sala, improvisando ares de entendido. Depois vae ao livro de visitas, rubrica uma assignatura, como elle nunca imaginara e sahe. O pintor olha para tudo isso com uns olhos desconsolados de artista que não perde a esperança, apezar de tudo. (MUNHOZ, 1922, p. 58).

Elementos como "catálogo", "livro de assinaturas", bem como o próprio termo salon são oriundos de uma tradição secular de exibição da produção artística nas academias europeias, e que em Curitiba apenas começava a se esboçar. A charge assinada por Mlle. Chy aponta para essa incongruência, e o seu olhar sobre o assunto indica certo repertório avantajado da autora.

Isso levanta algumas suposições sobre sua identidade: quem seria a senhorita espirituosa, possuidora de "lapis firme, caprichoso e rico de verve"?

Ainda que sem provas definitivas para afirmá-lo, poderia tratar-se de Marianna Coelho, poetisa e feminista atuante em Curitiba desde a década de 1890. Nascida em Portugal, veio morar no Brasil em 1892, estabelecendo-se em Curitiba13. Ao longo desse período, teve uma atuação relevante "na sociedade paranaense através de seu trabalho como educadora, escritora e defensora dos direitos da mulher" (KAMITA, 2004, p.10). Já Trindade (1992, p. 100) diz que Marianna Coelho e também Júlia Wanderley representavam "uma vanguarda na Curitiba da época", mas mesmo assim não iam muito além "do espírito de patriotismo que impregna o discurso educativo sobre a mulher"14. Quando muito, atingiram certa participação política que não

\footnotetext{
13 Tomo como referência os apontamentos de KAMITA (2004, p.10-12) sobre as incertezas acerca da data de nascimento de Marianna Coelho.

${ }^{14}$ Júlia Wanderley também era educadora em Curitiba, tendo sido a primeira mulher a ingressar no Instituto Paranaense em 1890, e a diplomar-se professora normalista naquela instituição.
} 
eliminava os velhos preconceitos sobre os direitos políticos e sociais da mulher ${ }^{15}$. Esses limites eram evidentes na atuação das mulheres de então.

Em 1898, Marianna elaborou uma crítica minuciosa sobre a exposição anual da Escola de Bellas Artes e Indústrias do Paraná, na ocasião ainda sob a batuta de Mariano de Lima. O texto completo foi publicado na década seguinte, como parte do livro Paraná Mental, de 1908, e consiste em rica memória sobre as atividades artísticas promovidas na cidade por Mariano de Lima ${ }^{16}$. Além de descrever as galerias expositivas e louvar alguns trabalhos, a autora destacou a má iluminação e a precariedade do espaço expositivo. (COELHO, 1908, p.132-133). Nas páginas finais da crítica, elencou alguns dos trabalhos que ela mais apreciou na exposição, e nomeou os alunos da escola que se distinguiam pela qualidade dos trabalhos.

Infelizmente, as pinturas e desenhos elogiados por ela não foram preservados, e não é possível confrontar a apreciação crítica com as obras em si. Mas é interessante notar que, num ambiente marcado pela ausência de crítica de arte, Marianna tenha se dedicado a escrever várias páginas de comentários à exposição de 1898. Esse fato faz suspeitar que pudesse ser ela a misteriosa senhorita a elaborar uma charge sobre o parco mercado de arte em Curitiba, mas trata-se apenas de suposição.

Além da crítica de arte, o livro Paraná Mental possui capítulos sobre literatura e jornalismo, sobre dramaturgia e sobre musicistas. Foi apresentado ao público com um proêmio de Rocha Pombo, no qual o literato diz ter sido um dos primeiros e mais solícitos "em aplaudir a inteligência e o coração de D. Marianna Coelho" que "surpreendeu os intelectuais do Paraná” (POMBO, in: COELHO, 1908, p.9). Como era de se esperar, esse livro escrito

\footnotetext{
${ }^{15} \mathrm{Na}$ opinião de Alexandra Padilha Bueno, (2010, p.20), o vínculo de Marianna com o irmão Teixeira Coelho, um filólogo emérito, foi "um fator decisivo para seu rápido ingresso, socialização e mesmo aceitação em meio à comunidade literária curitibana".

${ }_{16}$ Marianna conta que a exposição apresentou mais de 250 trabalhos, "executados por todos os processos até hoje" (COELHO, 1908, p.128) e que, conforme noticiado no jornal A República, teria sido visitada por mais de 3.600 pessoas ao longo de um mês. Informa que "nas galerias de pintura achavam-se expostos 153 trabalhos divididos em duas partes principais: óleo e aquarelas" (1908, p.129). Descreve a presença de retratos, pinturas com temas históricos, quadros de costumes, alegorias, cópias de quadros notáveis, além de paisagens e marinhas. Na seção de desenhos, com 90 trabalhos, descreve as técnicas: "ponta de lápis, crayon e esfuminho, fusem, pastel, etc." compondo diversos estudos de modelo vivo ou de gesso, além de cópias de pinturas célebres (1908, p.130). Na galeria de esculturas, 30 trabalhos de estatuaria, bustos e ornamentação decorativa.
} 
por uma mulher foi alvo de ironias e de crítica nos jornais e revistas do período, inclusive com "reclamações" por ela ter deixado de mencionar um rol de autores que se sentiram excluídos. Ainda assim, ela tinha apoio constante de alguns escritores, entre os quais Rodrigo Junior, editor literário de $A$ Bomba, colaborador de várias revistas de humor na Curitiba do início do século $\mathrm{XX}^{17}$.

Afora os textos sobre arte, Marianna Coelho teve outras participações na imprensa local. Como antes dito, já em 1901 ela escrevia, a convite de Celestino Junior, uma coluna no jornal Diário da Tarde intitulada Chronica da moda. No mesmo sentido, ela aparecia como a principal colaboradora do Album Feminino, "quinzenário de letras, artes, modas e variedades", publicado como suplemento de O Olho da Rua a partir de setembro de 1911. Mas mais surpreendente era o seu texto "Emancipação feminina", que ela publicara em 1900 na revista de arte Breviário, dirigida pelos poetas Romário Martins e Alfredo Coelho. Nesse texto, Marianna nega deliberadamente a "superioridade instructiva" dos homens sobre o sexo feminino, e diz que para acompanhar a transição social que vem sendo operada, a mulher "precisa cultivar e esclarecer o espírito", buscando atingir "um certo e justo paralelo com o espírito masculino" (BREVIÁRIO nº 1, 1900, p. 7). Diz, por fim:

Permittir, hoje, que a mulher permaneça amarrada ao deplorável poste da ignorancia, equivale a arriscal-a criminosamente a probabilidade de receber em compensação de seu mais nobre e espontâneo affecto, o completo anniquillamento da alma, o que quer dizer a sua principal ruina (BREVIÁRIO $\mathrm{n}^{\mathrm{o}} 1,1900$, p. 8).

Marianna Coelho era, enfim, defensora dos ideais feministas, convicta de que "a educação seria o caminho mais curto para se alcançar a emancipação feminina" (KAMITA, 2004, p.34 e 130). Em 1933, após publicar o livro Evolução do feminismo, ela foi convidada a participar do Centro de Letras do Paraná e homenageada numa sessão solene (O DIA, 1933, p. 4).

\footnotetext{
17 Rodrigo Junior era o pseudônimo adotado por João Batista Carvalho Oliveira (1887-1964). Ele inseriu os poemas de Marianna Coelho na sua obra Antologia Paranaense, publicada em 1938
} 


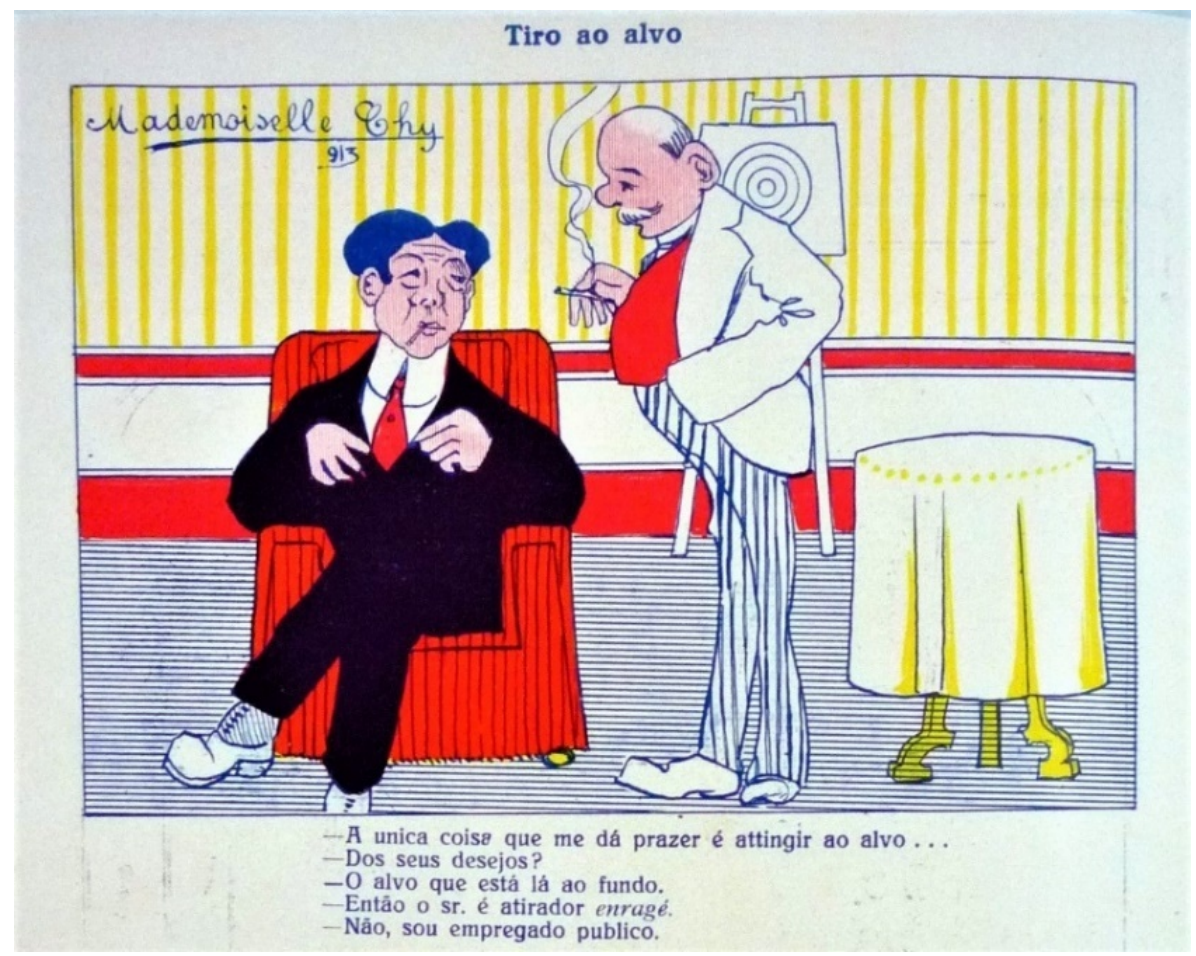

FIGURA 7: Charge assinada por Mademoiselle Chy. A Bomba, $31 \mathrm{dez} .1913$ n20-21, p.30.

- A unica coisa que me dá prazer é atingir ao alvo...

- Dos seus desejos?

- O alvo que está lá no fundo.

- Então o sr. É atirador enragé

- Não, sou empregado publico.

Quanto à Mademoiselle Chy, persiste o mistério. Também a segunda caricatura que ela publicou na revista poderia indicar se tratar de Marianna Coelho, pelo sarcasmo frente à falta de motivação no funcionalismo público (Figura 7). Naqueles anos, muitas críticas eram feitas à precariedade da instrução pública e à incompetência de alguns funcionários ${ }^{18}$. A charge ironiza a situação, indicando que a única ocupação interessante ao funcionário era passar o tempo brincando com os dardos de tiro ao alvo. No canto superior esquerdo, vê-se a assinatura da misteriosa Mademoiselle. A caligrafia de Mlle. Chy, além de aparentemente feminina, é professoral, pois muito se assemelha ao desenho cuidadoso e arredondado das letras praticado durante o processo de alfabetização. E Marianna Coelho era justamente proprietária de um colégio particular, o Santos Dumont, que dirigia desde janeiro de 1902 até 1917. A criação da escola foi noticiada no jornal A República em janeiro de

\footnotetext{
18 Ver, sobre o tema, o capítulo "Os serviços públicos” na dissertação de QUELUZ (1996, p.86-99).
} 
1902, e seu funcionamento amplamente publicizado por seus modernos métodos de ensino, ao longo dos anos seguintes.

No final das contas, apesar dessas suspeitas, não foram localizadas outras informações sobre a identidade da misteriosa desenhista. Além disso, o pequeno texto que informa sobre Mlle. Chy dizia que na ocasião ela "entrou para o corpo de colaboradores". Ora, se Marianna Coelho já era mencionada como colaboradora da revista desde seus primeiros números (Figura 8), não há coerência naquela suposição inicial de uma identidade comum. De qualquer modo, ambas participavam de um mesmo universo, o das mulheres que reivindicavam seu espaço ativo nos periódicos impressos.

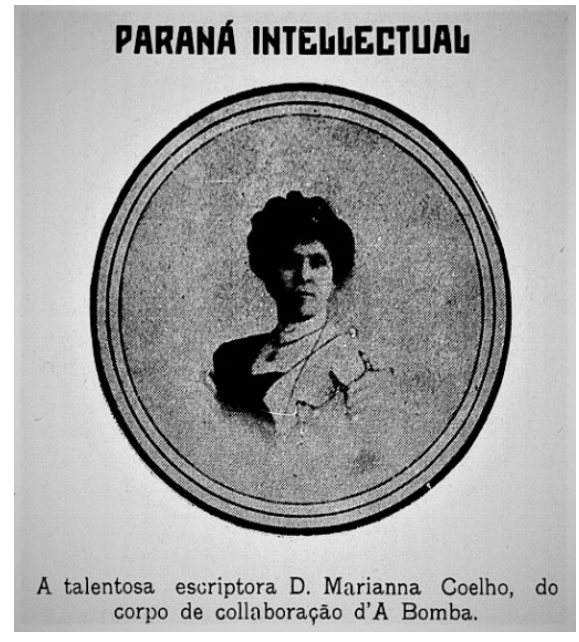

FIGURA 8: Nota sobre a participação de Mariana Coelho como colaboradora da revista $A$ Bomba, na seção "Paraná Intellectual”. A Bomba, n 12, 1913.

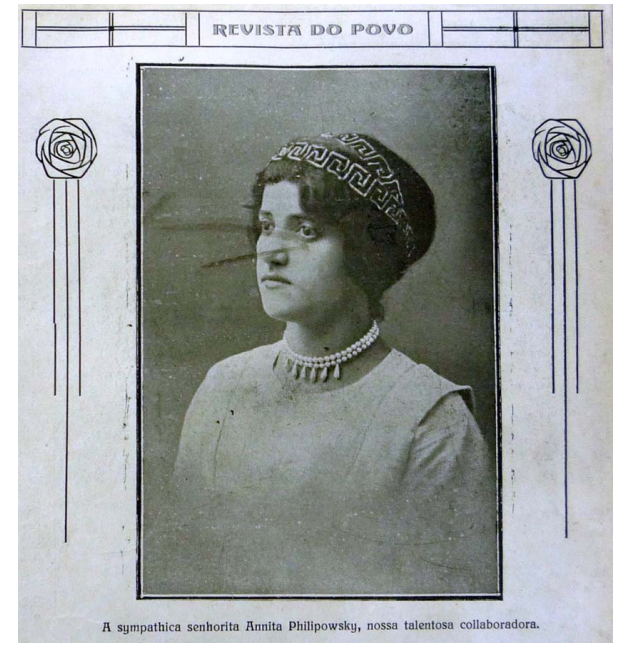

FIGURA 9: Fotografia de Annita Philipowsky, colaboradora nas revistas curitibanas A Bomba e Revista do Povo. Revista do Povo, edição $1^{\circ}$, outubro de 1916.

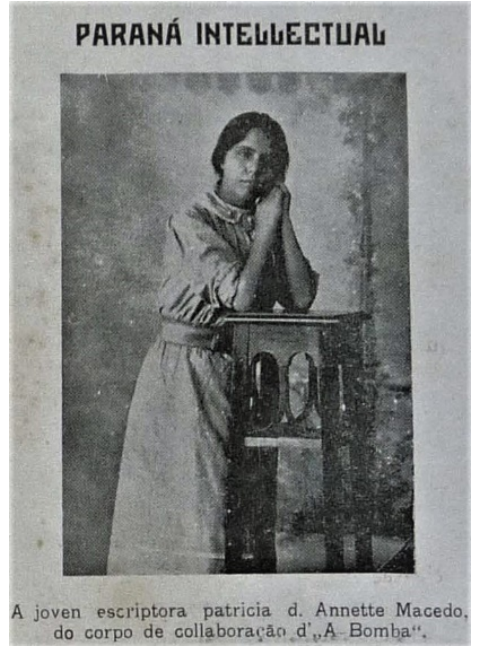

FIGURA 10: Fotografia de Annete Macedo, colaboradora da revista $A$ Bomba, na seção "Paraná Intellectual". A Bomba, $\mathrm{n}^{\mathrm{o}} 12,1913$.

Na seção "Paraná Intellectual" integrante da revista $A$ Bomba, tanto Marianna quanto várias outras mulheres foram homenageadas por atuarem como autoras de textos publicados na revista. Também se encontram menções à colaboração de "Annita Philipowsky (da geração novíssima de escriptoras paranaenses), nova colaboradora da revista, ao lado de Marianna Coelho, Myriam Cattapreta, Zaida Zardo, Aurea Pessoa e Annete Macedo" (A BOMBA $\left.1913, \mathrm{n}^{\circ} 7, \mathrm{p} .32\right)$.

Philipowsky colaborou também com a Revista do Povo em 1916, tendo sido homenageada já no primeiro número daquele periódico (Figura 9). Assim 
como elas, também Aurea Pessoa, Zaida Zardo e Annete Macedo (Figura 10) foram homenageadas com fotografias na seção "Paraná Intellectual".

Infelizmente, a edição que conteve as charges de Mlle. Chy foi a última publicação da revista $A B$ Bomba, e a promessa de que ela deliciaria os leitores com seus trabalhos caricaturais não foi cumprida. E, bem provavelmente, nenhuma dessas mademoiselles exaltadas na revista estava por detrás daquele pseudônimo. Não encontrei outras caricaturas de Mlle. Chy nas demais revistas ilustradas que circularam em Curitiba naqueles anos de proliferação gráfica. Se as poetisas e madames que assinavam colunas de modas nos jornais tinham suas fotos divulgadas e seus nomes celebrados, a produção de imagens não parecia ser motivo de orgulho para as mulheres.

\section{Sobre as mulheres produtoras de imagens}

Já discuti, noutro texto, sobre uma hierarquia social visível entre homens de letras e homens produtores de imagens na Curitiba do começo do século XX (KAMINSKI, 2017). Ali, considero que os "desenhistas de imprensa" - essa nova categoria de artistas que apareceu ao longo do século XIX e início do XX - são formadores de opinião que se posicionam por meio da linguagem de combate e da crítica dos costumes. No entanto, são geralmente considerados "artistas menores" em relação aos literatos e mesmo aos pintores, a partir de uma distinção já consolidada pelo uso. Se no universo dominado pelo masculino esses lugares já eram demarcados, o espaço para a atuação de mulheres era definitivamente limitado.

Isso não era exclusivo de Curitiba. Segundo a bibliografia que trata das questões de gênero nas artes, o lugar da artista visual mulher sempre foi dificultado e, inclusive, silenciado pelas narrativas históricas. Se escrever já foi difícil, "pintar, esculpir, compor música, criar arte foi ainda mais difícil. [...] As mulheres eram impróprias para isso" (PERROT, 2008, p.101). As mulheres puderam ser objeto de criação, mas não criadoras. Foram personagens de quadros e fotografias, mas raramente pintoras e fotógrafas. Figuras em mármore e gesso, mas não escultoras. Em seu livro, "A arte sem 
história”, Filipa Vicente (2012, p.19-20) pondera sobre os motivos pelos quais as mulheres podiam ser "artefatos culturais", mas não podiam participar da "produção de cultura", ainda que tantas tenham conseguido subverter os limites dessas imposições (VICENTE, 2012, p.25). A autora detecta duas vertentes principais da marginalização da prática artística feminina: em primeiro lugar, as condições socioculturais que afetaram cada "mulher artista", sempre "condicionada pela sua identidade enquanto mulher". Mesmo que alguns contextos tenham sido mais favoráveis do que outros, ter nascido mulher sempre foi um entrave à escolha de ser artista. Em segundo lugar, estariam as exclusões da própria construção histórica, sobretudo durante os séculos XIX e XX. Mesmo com as atuais intervenções feministas na história da arte, já não é possível dar voz plena a esses silenciamentos do passado, pois o "desprezo generalizado da produção artística realizada por mulheres ao longo dos séculos faz com que seja muito mais difícil encontrar documentos, visuais ou escritos, sobre o seu trabalho" (VICENTE, 2012, p.21) ${ }^{19}$.

Apesar de todas as dificuldades já apontadas para a atuação feminina no campo das produções visuais, Tamar Garb (1998, p.239) comenta que "na França do final do século XIX havia um número sem precedente de mulheres artistas trabalhando profissionalmente e transpondo a estrutura institucional do mundo artístico". Num contexto ideologicamente hostil à atuação pública feminina, a artista mulher tornou-se uma personagem padrão para os caricaturistas, geralmente representada como "mulher pouco feminina" ou "ingênua", como a figura 11 que ironiza a "mania de Belas Artes”. O fato de o modelo vivo para as duas aspirantes a artistas ser o próprio esposo / pai, situa a prática da pintura numa condição de "amadorismo", realizado no espaço domiciliar, tema que retomarei adiante.

\footnotetext{
19 Autoras como Linda Nochlin e Griselda Pollock, entre outras, produzem intervenções feministas na história da arte desde as décadas de 1970-80 até hoje, sob diversas abordagens.
} 


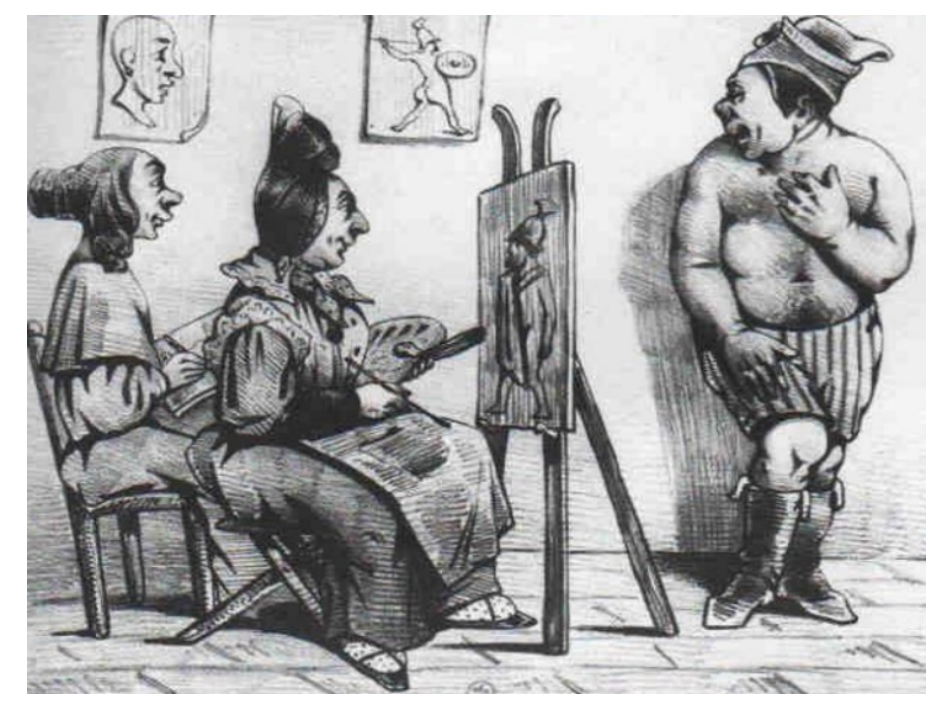

FIGURA 11: Caricatura que ridiculariza as mulheres no ofício da pintura. [Sa manie des Beaux arts. Litogravura de Pièces sur les arts, tomo 6, BN Kc. 164. Fonte: Fonte: Modernidade e Modernismo: $A$ pintura francesa no século XIX. Cosac \& Naify.1998, p. 241.

- "Vamos lá, Darancourt, seu grandíssimo palerma, você não está mais nas termas; você representa Aquiles e está posando na frente da sua mulher e da sua filha Clara.”

Do mesmo modo como apontado por essas autoras em relação ao contexto europeu, encontramos no Brasil, nos fins do século XIX e começo do século XX, registros bastante restritos sobre a participação de mulheres no mundo das artes. Ainda assim, algumas foram reconhecidas profissionalmente. Ana Paula Simioni (2008) comenta que no século XIX destaca-se nas cidades de Rio de Janeiro e São Paulo, a presença de pintoras como Abigail Andrade, Georgina de Albuquerque, Berthe Worms, e escultoras como Julieta de França e Nicolina de Assis Pinto do Couto, entre outras.

Em Curitiba, ainda que com menor visibilidade do que as artistas estudadas por Simioni, é relevante mencionar as atuações de Georgina Mongruel $^{20}$ no quadro docente da Escola de Belas Artes e Indústrias de Mariano de Lima; da já mencionada D. Maria da Conceição Aguiar de Lima, que foi aluna e depois diretora dessa mesma escola; e de Francisca Cândida de Munhoz, também aluna de Mariano de Lima desde 1886. Segundo consta

20 Georgina Mongruel era um poetisa belga que se estabeleceu em Curitiba em 1894, atuando principalmente como professora de piano e canto, mas também "ensinou francês, alemão, ciências naturais, matemática, desenho, aquarela e trabalhos de 'fantasia'. [...] "Juntamente com o marido que era artista e mestre de esgrima foi contratada pelo Conservatório de Bellas Artes". (TRINDADE, 1992, p.61). Além de ministrar aulas na Escola de Mariano de Lima, contribuiu com poesias, crônicas e crítica de arte em jornais e revistas tais quais Fanal, A Notícia, Diário da Tarde, Almanaque do Paraná, O Olho da Rua, O Cenáculo, Victrix, Escrínio, Fon-Fon, entre outros. 
em notas de jornais, ele chegou a ministrado aulas para ela ainda antes da inauguração de sua escola ${ }^{21}$. É possível arriscar, até, uma segunda suspeita, pois Francisca, conhecida na época por “Chiquinha Munhós”, poderia também ser a verdadeira identidade da misteriosa Mademoiselle Chy, autora das charges de 1913. Se isso pudesse ser constatado, ela já não seria uma mademoiselle, e sim uma madame, casada e com mais de 50 anos, visto que nascera em 1869.

Era filha de Alfredo Caetano Munhoz, então dirigente da Tesouraria de Fazenda nacional na Província do Paraná, e homem favorável à instrução das mulheres ${ }^{22}$. Além de brilhante nos estudos, Francisca conseguiu, de certa forma, se destacar no cenário cultural no final do século XIX e expor ao público local suas pinturas a crayon e a óleo. Pintava retratos, paisagens e cenas literárias. Ela está mencionada no livro "Paraná Mental", de Marianna Coelho (1908, p.138), como um dos muitos alunos (de ambos os sexos) que frequentaram a Escola de Mariano de Lima e salientaram-se em desenho e pintura. O jornal Dezenove de Dezembro, que várias vezes mencionou a sua participação nas exposições dessa escola, também anunciou, em meados de 1887, o seu matrimônio de Chiquinha com o engenheiro militar e alferes Carlos Cavalcanti de Albuquerque. A partir de então, ela seria sempre mencionada como "esposa” de Cavalcanti. Claudia Priori (2017, p.376-377) lamenta esse exemplo da situação de Francisca, pois mesmo sendo esmerada pintora e pianista, o seu destaque na imprensa (como o de outras mulheres) era dado pela "condição social e política que suas famílias ocupavam na sociedade curitibana do fim do século XIX".

A fotografia de Francisca Munhoz aos 18 anos de idade num atelier de pintura (Figura 12), que serviu de referência para a litografia de Narciso

\footnotetext{
${ }^{21}$ A edição de 2 de fevereiro de 1886 do jornal Dezenove de Dezembro publicou um artigo anônimo com o título "Bellas Artes" e o subtítulo "D. Francisca Candida Munhós". O texto elogia "D. Chiquinha Munhós" e menciona uma pintura de paisagem de sua autoria, numa tela de $50 \mathrm{~cm}$ exposta no "Bazar de Modas". Elogia seu pai (Alfredo Caetano Munhoz) pela filha talentosa e dá "mil parabéns ao Sr. Mariano de Lima, professor de Francisca". O mesmo jornal irá anunciar, em 24 de de julho de 1886, que Mariano de Lima ofereceu-se "para reger gratuitamente aula de desenho e pintura no Instituto Paranaense". Ou seja, antes da existência da Aula de Desenho e Pintura nas instalações do Instituto Paranaense, o português já ministrava aulas particulares a alguns alunos, entre eles Chiquinha.

22 Alfredo Caetano Munhoz era pai de Francisca, homem instruído, que sabia várias línguas e escrevia para periódicos da época. Em julho de 1898 publicou na revista A Colmeia n ${ }^{\circ} 1$ um texto intitulado "A Mulher", dedicado à escritora feminista Marianna Coelho. (TRINDADE, 1992, p.117 e 198).
} 
Figueras, publicada sob o título O Atelier na Revista do Paraná, em 1887

(figura 13), é significativa do lugar reservado à mulher no mundo da $\operatorname{arte}^{23}$.
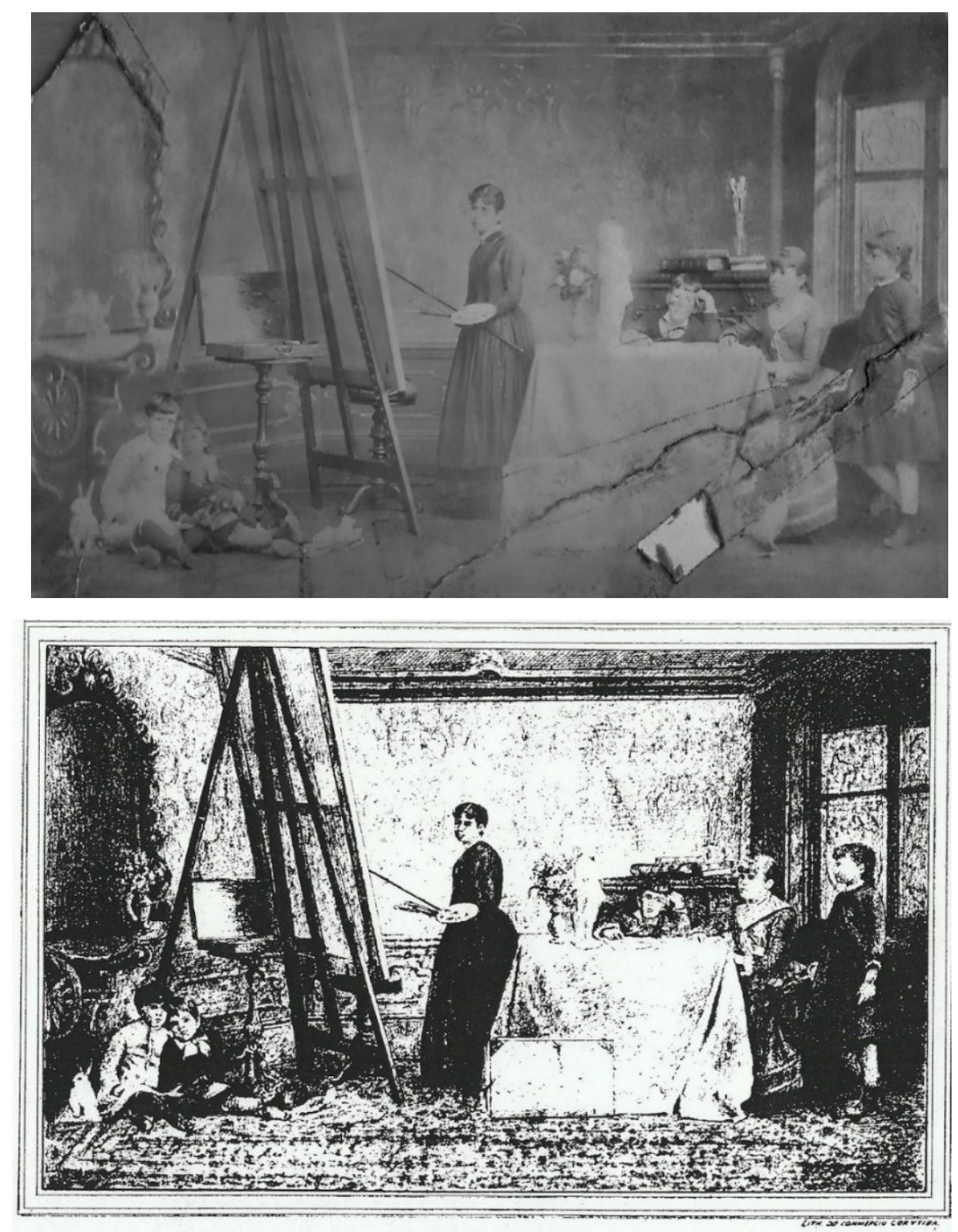

DIRANCISCA-MUNHOZ NO ATRLIER.

FIGURAS 12 e 13: Acima: "Francisca Munhoz no Ateliê". Curitiba, c. 1887. Acervo do Museu Alfredo Andersen. Abaixo: litogravura Atelier, publicada na Revista do Paraná n ${ }^{\circ} 1,1887$, p.5.

Tal imagem pode ser pensada dentro do conjunto de "retratos de artistas mulheres feitos por seus contemporâneos", conforme discute Garb:

23 A Revista do Paraná foi o primeiro periódico ilustrado de Curitiba, criado em 1887 pelo professor Nivaldo Braga, e com litografias feitas por Narciso Figueras, catalão responsável pela primeira oficina litográfica na cidade, a Litographia do Commercio (CARNEIRO, 1975, p.34-35). Sobre o suposto caráter ficcional dessa fotografia, sugiro ler: BUSNARDO, 2018, p.95-99). 
Não são, por si só, sinais de subversão dos papéis femininos tradicionais, mas invocam o mundo das realizações femininas. Quando combinados às convenções padronizadas do retrato feminino - o corpo inteiro elaboradamente vestido e adornado -, o potencial, em outros contextos, que tem de significar símbolos profissionais é desprezado (GARB, 1998, p.240244).

Nessa mesma edição que continha o retrato de Francisca, a Revista do Paraná publicou um texto celebrativo à Escola de Mariano de Lima, e destaca a presença de Francisca dentre os 117 alunos ali matriculados:

Uma aluna disctintissima pelo seu notável e invejável aproveitamente, a $\mathrm{Exm}^{\mathrm{a}} \mathrm{Sr}^{\mathrm{a}}$ D. Francisca Candida Munhoz Cavalcanti d'Albuquerque, mimosa e talentosa filha do Sr. Alfredo Caetano Munhoz, honrado e bem conceituado e considerado Inspector da Thesouraria da Fazenda, e virtuosa e ditosa esposa do Sr. Alferes Carlos Cavalcanti d'Albuquerque, á quem reverentemente rendemos sincera homenagem, enviando d'aqui um - Bravo - entusiástico, tanto do perseverante, devotado e incansável professor, Sr. Antonio Mariano de Lima, como dos seus não menos dignos discípulos [...]. (REVISTA DO PARANÁ n.1, 1887, p.6)

O uso publicitário feito a partir dessa fotografia, quando associado à boa imagem da escola de Mariano de Lima, confere um aspecto de adorno à fotografia de Francisca Munhoz. Adornar-se e "encantar" o olhar masculino era, no final das contas, a função primária esperada das mulheres (GARB, 1998, p.245), tal qual antes representado naquela alegoria de Curitiba (Figura 5). Não só no sentido de adorno físico, mas também pelas diversas virtudes descritas no trecho acima, que situam Francisca como um filha e esposa exemplar da elite curitibana. Sua presença na escola só podia ser considerada motivo de orgulho e atrativo para o estabelecimento.

Ela não pôde, no entanto, dar continuidade aos seus estudos e investir numa carreira profissional, pois o casamento realizado em julho daquele mesmo ano a levou a assumir as funções de esposa e mãe, adequando-se, no final das contas, às limitações sociais então impostas às mulheres. Portanto, 
supondo que Chiquinha Munhoz, anos mais tarde, produzisse charges e as tenha publicado em A Bomba sob o pseudônimo de Mademoiselle Chy, é bem compreensível que ela precisasse esconder sua identidade, ainda mais que na ocasião da publicação, ela já era a primeira dama do Paraná: Carlos Cavalcanti de Albuquerque viria a ser presidente do Paraná entre os anos de 1912 e 1916. Os jornais já não exaltavam a atuação de Francisca Munhoz Cavalcanti como pintora, mas ainda atestavam que ela mantinha proximidade com a arte, como pode ser constatado na nota publicadas em $A$ República (1913, p.2) sobre sua participação como membro do conselho superior da seção de pintura do "Centro Artístico do Paraná", em formação naquele ano.

Também com atuação no início do século XX, há que se mencionar o caso significativo de Maria Amélia D’Assunção, que se destacou na pintura dentre os alunos do mestre norueguês Alfredo Andersen. Conforme discorre Cláudia Priori (2017, p. 378), Maria Amélia teve uma educação esmerada, era apaixonada por leituras e aprendeu diversas línguas. Em 1910, viúva do primeiro casamento e mãe de um filho, ainda com o nome de Maria Amélia de Barros Mota, ela fixou residência em Curitiba e procurou dedicar-se à pintura para ter um meio de sobrevivência, e para educar seu filho (ARAÚJO, 1973). Ingressou, então, como aluna no atelier de Andersen e, aos poucos, foi se destacando pela qualidade de seus trabalhos, sobretudo naturezas-mortas. Em 1917, tornou-se a primeira mulher do Paraná a expor suas obras, individualmente, no Rio de Janeiro.

Nessa exposição, ela teria sido acompanhada pelo advogado Pamphilo d'Assumpção (BATISTA, 1979), admirador das artes e simpático, em certa medida, ao discurso feminista (TRINDADE, 1992, p. 113) ${ }^{24}$. Casou-se com ele em 1920, assumindo o nome de Maria Amélia d'Assumpção. Obteve, desde então, o apoio do marido (PRIORI, 2017, p. 379). Maria Amélia D’Assumpção lecionou pintura e desenho no Colégio Santa Júlia, do Professor Francisco Guimarães e na Escola Profissional Feminina, além de ministrar aulas

\footnotetext{
${ }^{24}$ Ainda que simpático à valorização social da mulher, as declarações públicas do jurista esbarravam, contudo, nas alegações do papel preferencial da esposa no recinto do lar (TRINDADE, 1992, p.133).
} 
particulares e dedicar-se à pintura. No entanto, sua posição era bastante conservadora frente aos debates feministas. Numa publicação datada de 1927 acerca do direito da mulher votar, Maria Amélia se posicionava de forma cautelosa, e coerente com a opinião do seu próprio marido:

Para todas as mulheres que não querem se rebelar contra as leis naturaes, creio que seu interesse e devotamento para a Patria, ellas demonstram criando os filhos, fazendo com que se tornem uteis para o trabalho, como respeitadores da ordem social, bons chefes de família e que sobretudo amem o Brasil abnegadamente e criando filhas que como mae e esposas sigam esse mesmo ideal. Assim ellas contribuirão mais para a grandeza da nossa querida Patria, do que com a interferência perturbadora do voto (A RUA, 1927, p.3).

Vale observar que na mesma nota de jornal, há a informação de que Maria Amélia era "esposa do jurista Dr. Pamphilo Assumpção, o qual nega o direito de voto da mulher brasileira" (A RUA, 1927, p.3). A simpatia de Pamphilo à causa feminista tinha, portanto, seus limites, o que era completamente aceitável numa sociedade heterogênea, composta por numerosos grupos que compunham o conjunto do pensamento curitibano. Apesar do debate feminista permear as páginas de periódicos já nos primeiros anos do século, suas conquistas foram lentas e, na maioria dos países, como também no Brasil, o direito ao voto, grande bandeira do movimento, só foi atingido a partir dos anos 1920 e 30. (TRINDADE, 1992, p.113). 
Além dessas e outras mulheres que, nem sempre feministas, mas dispostas a ocupar um espaço ativo na produção visual em Curitiba, também vale a pena mencionar a fotógrafa Fanny Paul Volk, radicada na cidade a partir de $1881^{25}$. Ela era sóciafundadora do Estúdio Volk, geralmente associado apenas ao nome do fotógrafo alemão Adolpho Volk, com quem Fanny se casou em 1886, cinco anos após a inauguração do estúdio (SIMÃO, 2010, p.32). No entanto, após a separação do casal e a partida de Adolpho para a

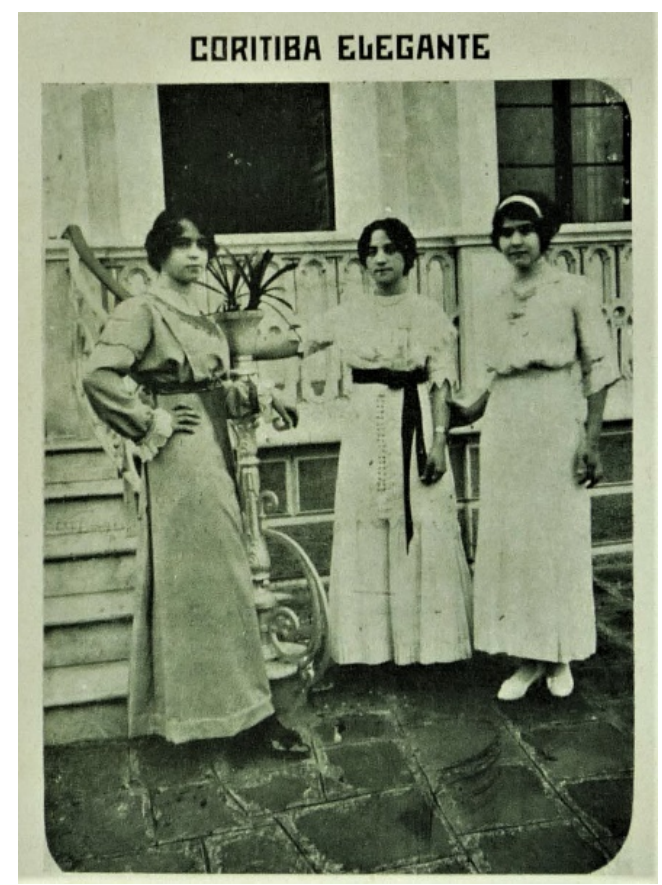

FIGURA 14: Coritiba Elegante. Fotografia publicada na revista $A B o m b a \mathrm{n}^{\circ} 19,1913$. (As graciosas senhoritas Eustachio Silva, Esther Lacerda e Ondina Borba).

Alemanha, em 1904, ela permaneceu

dirigindo o estúdio fotográfico até 1918 (Ibidem, p. 29 e 301). Sendo assim, todas as fotografias com flagrantes sociais ou paisagens curitibanas publicadas sob o carimbo do Estúdio Volk na revista A Bomba, estavam sob a responsabilidade da Fanny. Ainda que vários fotógrafos tenham trabalhado para ela ao longo daqueles anos, e que o nome do Estúdio se sobressaísse em relação à sua pessoa (provavelmente por ser mulher), tudo passava pela sua supervisão.

\section{Amadoras e operárias}

\footnotetext{
${ }^{25}$ A tese de Giovana Simão dedica-se ao caso de Fanny Paul Volk, problematizando a presença de uma mulher no ofício fotográfico em Curitiba numa época em que "a estrutura social da cidade ainda não oferecia tal lugar para as mulheres, especialmente, em ofícios imagéticos como era o caso da pintura e da fotografia” (SIMÃO, 2010, p.5). Vale lembrar que a mãe de Fanny, Anna Paul, também era fotógrafa.
} 


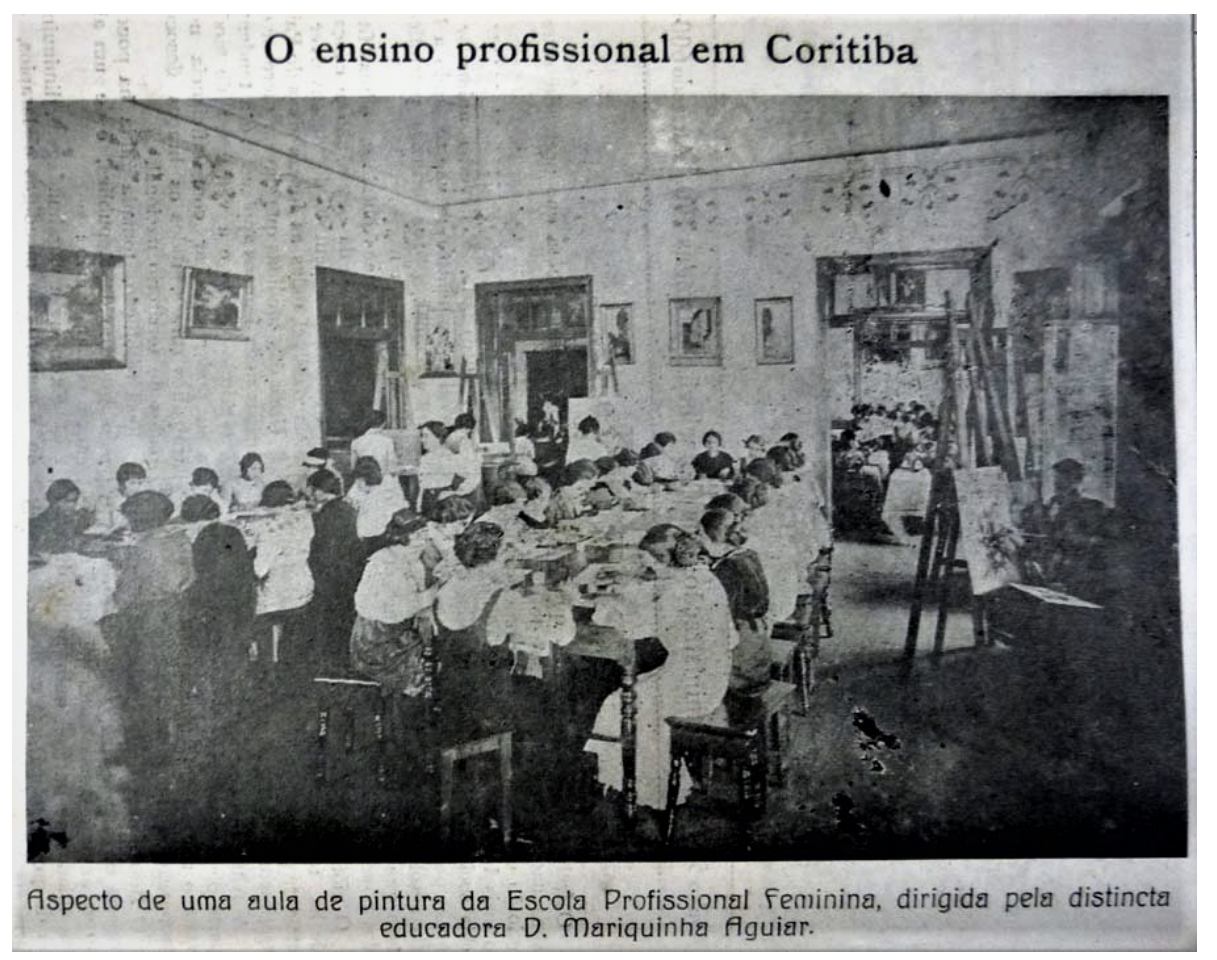

FIGURA 15: "O ensino profissional em Coritiba".

Fotografia da Escola Profissional Feminina. Revista do Povo, n¹3. Curitiba, 1917.

Com exceção de Maria Amélia Assumpção, que obteve um certo reconhecimento num espaço artístico majoritariamente masculino, todas as as outras mulheres aqui mencionadas adequavam-se mais às categorizações de "pintora-amadora" ou de "artista operária", indicadas por Filipa Valente quando discorre sobre o século XIX ${ }^{26}$. A "pintora-amadora", tal qual Francisca Munhoz e diversas outras mulheres que frequentaram as aulas de Mariano de Lima e de Alfredo Andersen, era aquela que praticava as artes, no espaço privado, sem ser artista profissional. Já a "artista operária", conceito associável aos casos da fotógrafa Fanny Volk e também de Maria Aguiar e sua Escola Profissional Feminina (Figura 15), desdobrada da antiga Escola de Belas Artes e Indústrias do Paraná, refere-se a um lugar demarcado pela distinção bem evidente naqueles anos entre "artes maiores" e "artes menores" (artes decorativas, produção industrial) na qual, para além da hierarquia

26 Capítulo intitulado "Identidade artística no século XIX: a artista-amadora, a artista-operária e a artista-masculina” (VICENTE, 2012, p. 153-178). 
entre as artes, também se articulava uma diferenciação sexual (VICENTE, 2012, p.153-160) ${ }^{27}$.

Ao longo do século XIX e início do XX, as denominadas artes menores, quer praticadas de forma profissional, quer no interior dos lares, foram caracterizadas como sendo "artes femininas". Não era proibido à mulher praticar artes visuais, mas esse lugar "menor" dedicado ao trabalho feminino fez com que seus trabalhos não fossem identificados como arte, contribuindo para sua desvalorização.

Os entraves a que as mulheres participassem nas "artes maiores" contrastavam com o incentivo a que se dedicassem às "artes menores", compreendendo nelas todas as formas de produção artística onde não se considerava tão necessário o uso do intelecto, da imaginação, da invenção e da originalidade (VICENTE, 2012: 26).

Outro aspecto ligado à noção de artes menores, no que diz respeito aos novos processos técnicos e industriais, nos quais muitas mulheres atuaram, é que geralmente limitava-se ao trabalho anônimo, não assinado. Isso fica evidente no caso das fotografias de Fanny Volk em Curitiba, cujo trabalho de atribuição foi recentemente feito por Giovana Simão a partir do período de sua administração do estúdio e de certas recorrências e características estilísticas, visto que as suas fotos, produzidas sempre a partir da égide da empresa que levava o nome do marido, não são $\operatorname{assinadas}^{28}$.

Enfim, para concluir estas reflexões, volto a reiterar a quase absoluta ausência de mulheres produtoras de charges no contexto da virada do século XIX para o XX (exceção para a misteriosa Mademoiselle Chy); a significativa presença da fotógrafa Fanny Paul Volk com atuação ativa em Curitiba e responsável pelo estúdio produtor de fotografias para várias revistas publicadas na cidade, e também a de outras artistas mulheres mencionadas ao longo do texto. Ainda assim, tanto no âmbito literário quanto no visual

27 "Havia, assim, um espaço público, exemplificado pelas escolas ou pelas fábricas indissociáveis da industrialização oitocentista, onde o trabalho artístico das mulheres já era aceitável, como acontecia com as "artistas-operárias"." (VICENTE, 2012, p.26).

${ }^{28}$ Na tese de Simão (2010, p.48), "a partir de 1903, o crédito das fotografias são atribuídas a Fanny Paul Volk pelo fato de sua mãe já ter falecido e pelo fato de Volk ter regressado para a Alemanha”. 
predomina, se não hegemonia da masculinidade da criação artística, ao menos um direcionamento dos méritos de criação artística para indivíduos masculinos, mesmo quando da existência de produções femininas. É preciso concordar com Filipa Vicente (2012: 22) quando diz que "as mulheres artistas constituíam a excepção à norma", e que "quando a prática artística das mulheres não era excluída, tendia a ser inferiorizada” (Ibidem, p.27). Não era de se estranhar, portanto, que Mademoiselle Chy preferiu manter seu anonimato, diferente das colaboradoras literárias de $A$ Bomba, que não só assinavam seus textos, como foram homenageadas com fotografias (provavelmente feitas por Fanny) na seção "Paraná Intellectual".

\section{Referências}

ARAÚJO, Adalice. Maria Amélia, pioneira da arte no Paraná. Diário do Paraná. Curitiba, 25 de fevereiro de 1973.

BATISTA, Nery. Quem foi Maria Amélia? Gazeta do Povo. Curitiba, 15 de outubro de 1979.

BUENO, Alexandra Padilha. Educação e participação política: a visão de formação feminina de Mariana Coelho. Dissertação de Mestrado em Educação. Curitiba, UFPR, 2010.

BUSNARDO, Larissa. Fotografias pictóricas, pinturas fotográficas: a circulação de imagens em Curitiba (1881-1918). Dissertação de Mestrado em História. Curitiba, UFPR, 2018.

CARNEIRO, Newton. O Paraná e a caricatura. Curitiba: MAC / Grafipar, 1975.

Centro de Letras do Paraná. O Dia. Curitiba, 24 de novembro de 1933.

COELHO, Marianna. Emancipação da Mulher. Breviário. Curitiba, 1900.

Paraná Mental. Curytiba: Typographia da Livraria Econômica, 1908.

CUNHA, Renata Thereza Fagundes et al. A feminização da cultura: Curitiba, 18901930. Dissertação de Mestrado em História. Campinas, UNICAMP, 2001.

D. Francisca Candida Munhoz Cavalcanti Albuquerque no "Atelier". Revista do Paraná, n.1, 1887, p.4-6.

FAKIN, Marusa. Moda, instrucción y feminismo: revistas culturales destinadas al bello sexo. In: FAKIN, M.; MUSSER, R.; y STEINKE, B. (eds.). Interconexiones, transferências e información: revistas culturales latinoamericanas. Berlin: Instituto Iberoamericano, 2019. 
GARB, Tamar. Gênero e representação. In: FRASCINA, Francis; GARB, Tamar; BLAKE, Nigel; FER, Briony; HARRISON, Charles. Modernidade e modernismo: a pintura francesa no Século XIX. São Paulo: Cosac \& Naify, 1998, p. 220 a 289.

KAMINSKI, Rosane. O belo efêmero, o gosto brejeiro: imagens da vida fugidia nas revistas curitibanas (1900-1920). Disponível em: http://www.revistascuritibanas.ufpr.br/artigos.php

Gosto brejeiro: as revistas ilustradas e a formação de juízos estéticos em Curitiba (1900-1920). In: BREPOHL, M.; CAPRARO, A.; GARRAFFONI, R. Sentimentos na história: linguagens, práticas, emoções (org.). Curitiba: Ed. UFPR, 2012.

Aureliano Silveira entre prensas, penas e nanquins. In: COSTA, Hilton; PEGORARO, Jonas W.; STANCZYK FILHO, Milton (Org.). O Paraná pelo caminho: histórias, trajetórias e perspectivas. Volume 1 (Imagens). Curitiba: Máquina de Escrever, 2017.

KAMITA, Rosana Cássia. Resgates e ressonâncias: Marianna Coelho. Tese de Doutorado em Literatura, Universidade Federal de Santa Catarina. Florianópolis, UFSC, 2004.

MUNHOZ, Laertes. Alguns artistas paranaenses: annotações de Laertes Munhoz. Jornal Gazeta do Povo, Curitiba, 7 set. 1922, p.58-62.

O voto feminino. A Rua: semanário ilustrado. Rio de Janeiro, 26 de novembro de 1927.

QUELUZ, Marilda Lopes Pinheiro. Olho da Rua: o humor visual em Curitiba (1907-1911). Dissertação de Mestrado em História, Universidade Federal do Paraná, Curitiba, 1996.

. As representações da mulher na revista A Bomba (1913). Anais do IV Forum de Pesquisa Científica em Arte. Curitiba, EMBAP, 2006.

Pelas artes: notas do Centro Artístico. A República, Curitiba, 15 de abril de 1913, p.2.

PERROT, Michelle. Minha história das mulheres. São Paulo: Contexto, 2008.

PRIORI, Cláudia. Mulheres e a pintura paranaense: relação entre arte e gênero. História: Questões \& Debates, Curitiba, volume 65, n.1, p. 359-384, jan./jul. 2017.

SANTANA, Luciana Wolff Apolloni. Escola de Belas Artes e Indústrias do Paraná: o projeto de ensino de artes e ofícios de Antônio Mariano Lima - Curitiba, 1886-1902. Dissertação de Mestrado em Educação. Curitiba: UFPR, 2004.

SIMÃO, Giovana Terezinha. Fanny Paul Volk: pioneira na fotografia de estúdio em Curitiba. Tese de doutorado em Sociologia. Curitiba, UFPR, 2010.

SIMIONI, Ana Paula Cavalcanti. Profissão Artista: Pintoras e Escultoras Acadêmicas brasileiras. São Paulo: Fapesp, 2008. 
TEIXEIRA, Nincia Borges. N'O Olho da Rua: imprensa paranaense e a representação social da mulher. Todas as Letras, São Paulo, v. 16, n. 1, p. 139-150, maio 2014.

. Entre o público e o privado: imprensa e representação feminina. Revista Encuentros, Universidad Autónoma del Caribe, 12 (2), pp. 79-92, july/dec. 2014.

TRINDADE, Etelvina Maria de Castro. Clotildes ou Marias: mulheres de Curitiba na Primeira República. Tese de Doutorado em História. São Paulo, USP, 1992.

VICENTE, Filipa Lowndes. A arte sem história: mulheres e cultura artística (Séculos XVI-XX). Lisboa: Babel, 2012.

WACHOWICZ, Ruy Christovam. História do Paraná. 7 ed. Curitiba: Editora e Gráfica Vicentina, 2010.

Recebido em maio de 2019. Aprovado em julho de 2019. 